\title{
An alternative pathway for production of acetonitrile: ruthenium catalysed aerobic dehydrogenation of ethylamine
}

Corker, Emily; Mentzel, Uffe Vie; Mielby, Jerrik Jørgen; Riisager, Anders; Fehrmann, Rasmus

Published in:

Green Chemistry

Link to article, DOI:

$10.1039 /$ c3gc36513a

Publication date:

2013

Document Version

Publisher's PDF, also known as Version of record

Link back to DTU Orbit

Citation (APA):

Corker, E., Mentzel, U. V., Mielby, J. J., Riisager, A., \& Fehrmann, R. (2013). An alternative pathway for production of acetonitrile: ruthenium catalysed aerobic dehydrogenation of ethylamine. Green Chemistry, 15(4), 928-933. https://doi.org/10.1039/c3gc36513a

\section{General rights}

Copyright and moral rights for the publications made accessible in the public portal are retained by the authors and/or other copyright owners and it is a condition of accessing publications that users recognise and abide by the legal requirements associated with these rights.

- Users may download and print one copy of any publication from the public portal for the purpose of private study or research.

- You may not further distribute the material or use it for any profit-making activity or commercial gain

- You may freely distribute the URL identifying the publication in the public portal 


\section{Green Chemistry}

RSCPublishing

\section{PAPER}

Cite this: Green Chem., 2013, 15, 928

Received 25th September 2012,

Accepted 18th February 2013

DOI: $10.1039 / c 3 g c 36513 a$

www.rsc.org/greenchem

\section{An alternative pathway for production of acetonitrile: ruthenium catalysed aerobic dehydrogenation of ethylamine}

\author{
Emily C. Corker, ${ }^{a}$ Uffe V. Mentzel, ${ }^{a, b}$ Jerrik Mielby, ${ }^{a}$ Anders Riisager ${ }^{a}$ and \\ Rasmus Fehrmann*a
}

\begin{abstract}
The oxidative synthesis of acetonitrile from ethylamine was studied using a supported ruthenium catalyst. The reaction was conducted in both batch and flow processes and high conversions (over 85\%) were achieved in both cases. Selectivity of both reactions was improved by optimisation of reaction conditions, achieving over $90 \%$ selectivity in the batch process and $80 \%$ selectivity in the continuous flow process. The use of a selective solid catalyst that utilises a feedstock that can be derived from biomass, dioxygen as the oxidant and water as the solvent represents a new, green route for the independent and efficient production of acetonitrile.
\end{abstract}

\section{Introduction}

Acetonitrile is a bulk chemical with a large number of applications including its use as a solvent and an intermediate for pharmaceutical, agricultural and materials chemistry. ${ }^{1}$ Acetonitrile is currently produced as a by-product during the ammoxidation of propylene to acrylonitrile. ${ }^{2-4}$ The recent acetonitrile crisis of $2009,{ }^{5}$ coupled with the reliance of acetonitrile production on petrochemical resources, highlights the need for an independent, efficient process for the production of acetonitrile from sustainable resources.

Previously reported alternative routes to acetonitrile include the ammoxidation of ethane ${ }^{5,6}$ and ethanol, ${ }^{7,8}$ though both routes appear to suffer from disadvantages such as high ammonia to reactant ratios, low conversion or low selectivity to acetonitrile. A third option may involve the production of acetonitrile from ethanol or bioethanol via ethylamine (Scheme 1). Ethylamine is presently produced on a large scale

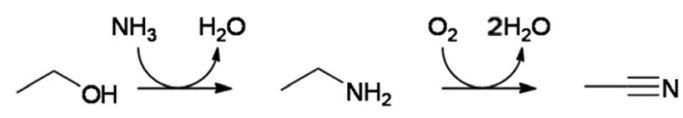

Scheme 1 Formation of acetonitrile from ethanol via ethylamine. from ethanol and ammonia, ${ }^{9}$ rendering ethylamine a readily available starting material. The present work focuses on the development of the second reaction step, in which ethylamine is converted to acetonitrile.

Routes for the synthesis of nitriles from amines, such as acetonitrile from ethylamine, using stoichiometric oxidants have been known for some time. ${ }^{10-12}$ However, the use of atmospheric oxygen as an oxidant for the production of nitriles from amines is attractive as only $\mathrm{H}_{2} \mathrm{O}$ is generated as a side-product (Scheme 1). There have been many studies reported regarding the selective oxidation of alcohols using molecular oxygen and heterogeneous catalysts, but the selective oxidation of amines with $\mathrm{O}_{2}$ or air has been somewhat neglected. However, recently Yamaguchi et al. published a series of studies involving ruthenium hydroxide based catalysts for a number of functional group transformations with $\mathrm{O}_{2}$ and ammonia, ${ }^{13-18}$ including the synthesis of aromatic and long chain aliphatic nitriles from amines using $\mathrm{O}_{2}$ as the oxidant. ${ }^{19}$ The described $\mathrm{Ru}(\mathrm{OH})_{x} / \mathrm{Al}_{2} \mathrm{O}_{3}$ catalyst was efficient for the tested transformations, though it was not applied to short chain aliphatic nitriles and reactions were only conducted in batch processes.

In recent years there has been an emergence of flow chemistry for functional group transformations, both within laboratories $^{20,21}$ and industry. ${ }^{22}$ The use of continuous flow processes offers advantages such as improved safety, efficient catalyst separation, improved space economy, reproducibility, automation and process reliability. For this reason, the work on the conversion of ethylamine to acetonitrile presented here was performed in both a batch reactor and in a gas-phase, continuous flow reaction setup. 


\section{Experimental}

\section{Catalyst synthesis and characterisation}

The $\mathrm{RuO}_{x} / \mathrm{Al}_{2} \mathrm{O}_{3}$ catalyst was synthesised with a target $\mathrm{Ru}$ loading of $2.4 \mathrm{wt} \%$ by deposition precipitation using a method analogous to the method previously reported by Yamaguchi et $a l .{ }^{16} 0.25 \mathrm{~g} \mathrm{RuCl}_{3}$ hydrate $(38-42 \mathrm{wt} \% \mathrm{Ru})$ was dissolved in $143 \mathrm{ml}$ of distilled water. $4.9 \mathrm{~g} \mathrm{Al}_{2} \mathrm{O}_{3}$ (Saint-Gobain) was added to the solution to form a slurry which was stirred for 15 minutes. $1 \mathrm{M} \mathrm{NaOH}$ solution was added to the slurry to adjust the $\mathrm{pH}$ to 13.5. The slurry was then stirred at room temperature for 18 hours. The resulting dark green powder was filtered, washed with distilled water and dried at $140{ }^{\circ} \mathrm{C}$.

The BET surface areas were analysed by $\mathrm{N}_{2}$ physisorption using a Micromeritics ASAP 2020. XRPD analysis was carried out using a Huber G670 diffractometer with an exposure time of 30 minutes and an incident wavelength of $1.54060 \AA$.

SEM images were obtained using a Quanta 2000 ESEM FEG microscope, equipped with a field emission gun electron source, an Everhart-Thornley secondary electron detector and an Oxford Instruments $80 \mathrm{~mm}^{2} \mathrm{X}$-max SDD EDS detector. The catalyst was mounted on carbon tape and coated with $\mathrm{Au}$ using a Cressington 208HR Sputter Coater, $40 \mathrm{~mA}$ current for 10 seconds, before SEM analysis. TEM images were obtained using an FEI Tecnai T20 G2 microscope, equipped with a Thermionic - LaB6 electron source, a Gatan 894 2K UltraScan 1000 camera and a $2 \mathrm{~K}$ UltraScan $1000 \mathrm{FT}$ camera and operated at $200 \mathrm{kV}$. The catalyst was dispersed on an amorphous carbon film TEM grid prior to analysis.

XRF analysis was performed using a Panalytical Axios wavelength dispersive X-ray fluorescence spectrometer. The sample was mixed with micro-crystalline cellulose and pressed into a solid pellet for analysis.

\section{Catalyst activity testing}

Oxidation of ethylamine in the batch reactor was typically conducted as follows: $0.425 \mathrm{~g}$ of $\mathrm{RuO}_{x} / \mathrm{Al}_{2} \mathrm{O}_{3}$ catalyst $(<180 \mu \mathrm{m}$ size fraction) was loaded into a Teflon cup. $800 \mu \mathrm{l}$ of aqueous $70 \%$ ethylamine solution, $215 \mu \mathrm{l}$ of dioxane (internal standard) and $2985 \mu \mathrm{l}$ of water (or aqueous ammonia where appropriate) were added to give a total volume of $4 \mathrm{ml}$. The Teflon cup was loaded into a Parr autoclave reactor and pressurised to $10 \mathrm{bar}$ with $\mathrm{O}_{2}$. The autoclave was heated with stirring to the desired reaction temperature (typically $80-100{ }^{\circ} \mathrm{C}$ ) for the desired time (1-24 hours). The reaction temperature was measured by a thermocouple inside the Teflon cup. When the reaction time was complete, the autoclave was allowed to cool. The reaction mixture was filtered and analysed by GC (Agilent 6890). Product concentrations were calculated by reference to the internal standard. A similar process was used when THF was used as the solvent in batch reactions with $5.05 \mathrm{ml}$ of $2 \mathrm{M}$ ethylamine in THF.

Catalytic tests under flow conditions were carried out in a fixed bed quartz reactor charged with $300 \mathrm{mg}$ catalyst (180-350 $\mu \mathrm{m}$ size fraction). Catalysts were calcined at 150-350 ${ }^{\circ} \mathrm{C}$ in air or $\mathrm{He}$ in the reactor before the reaction.
The reactant liquid (10 wt $\%$ ethylamine in water) was introduced by an HPLC pump and evaporated before reaching the reactor $\left(\mathrm{WHSV}_{\text {ethylamine }}=1.0 \mathrm{~h}^{-1}\right)$. Air and helium were introduced by mass flow controllers and the total gas flow (including ethylamine and water vapour) was kept constant at $150 \mathrm{~cm}^{3} \mathrm{~min}^{-1}$ in all experiments. All experiments were performed at a total pressure of 1 bar and the reaction temperature was measured inside the reactor, just below the catalyst bed. The product mixture travelled in heated lines from the reactor to an online GC (Agilent 6890) equipped with a flame ionization detector and an automated gas injection system. $\mathrm{CO}$ and $\mathrm{CO}_{2}$ were monitored continuously by a BINOS detector situated after the GC.

All chemicals for synthesis and activity testing were obtained from Sigma-Aldrich unless otherwise stated and used as received.

\section{Results and discussion}

\section{Catalyst characterisation}

XRPD analysis of both the calcined and uncalcined $\mathrm{RuO}_{x} /$ $\mathrm{Al}_{2} \mathrm{O}_{3}$ catalysts showed the presence of highly amorphous $\gamma-\mathrm{Al}_{2} \mathrm{O}_{3}{ }^{23}$ and $\mathrm{RuO}_{2}{ }^{24}$ as shown in Fig. 1. XRPD analysis of the uncalcined catalyst showed only broad, undefined peaks, while analysis of the $350{ }^{\circ} \mathrm{C}$ calcined catalyst showed sharper peaks corresponding to the $\mathrm{RuO}_{2}$ phase, suggesting a larger average crystallite size or a greater degree of crystallinity. Analysis using the Debye-Scherrer equation suggested $\mathrm{RuO}_{2}$ nanoparticles in the calcined catalyst with an average crystallite size of 20-25 nm.

The catalyst was imaged by SEM and analysed using EDS to determine elemental composition. SEM images showed catalyst particles of varying sizes of up to $20 \mu \mathrm{m}$, as seen in Fig. 2. The ruthenium metal loading was found to be $1-3 \mathrm{wt} \%$ by EDS. Small nano-scale features were observed on the surface of the catalyst. These could be presumed to be ruthenium

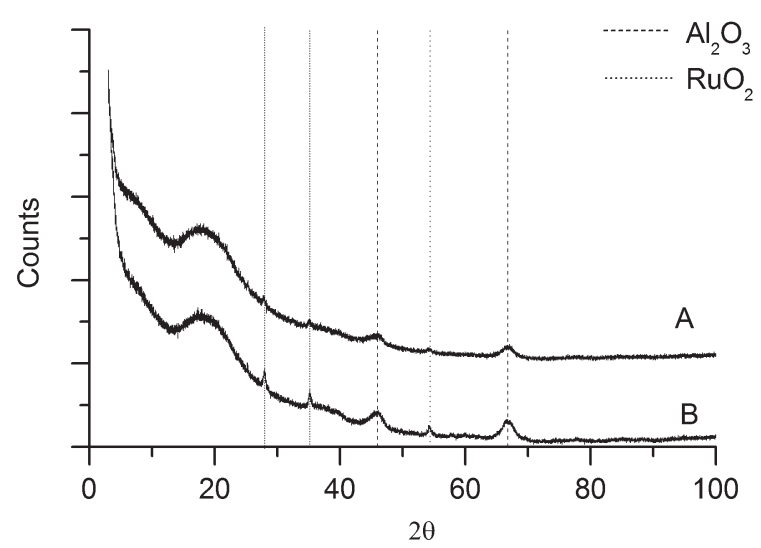

Fig. 1 XRPD analysis of the $\mathrm{RuO}_{x} / \mathrm{Al}_{2} \mathrm{O}_{3}$ catalyst uncalcined $(\mathrm{A})$ and calcined in air at $350{ }^{\circ} \mathrm{C}$ (B). Inserted lines correspond to $2 \theta$ values of major peaks of $\gamma-\mathrm{Al}_{2} \mathrm{O}_{3}{ }^{23}$ and $\mathrm{RuO}_{2}{ }^{24}$ obtained from the literature. 

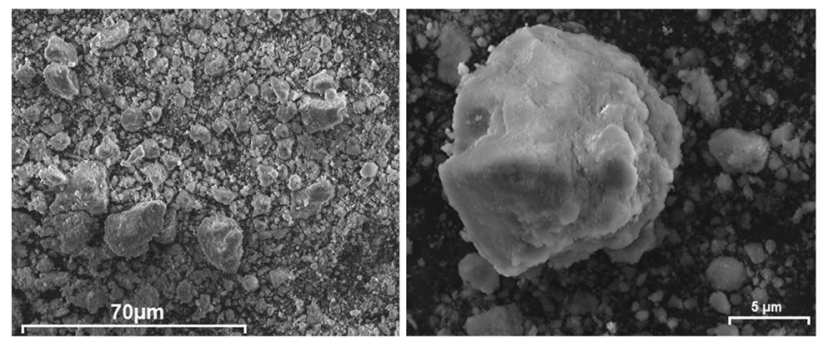

Fig. 2 Secondary electron SEM images of the $\mathrm{RuO}_{x} / \mathrm{Al}_{2} \mathrm{O}_{3}$ catalyst.

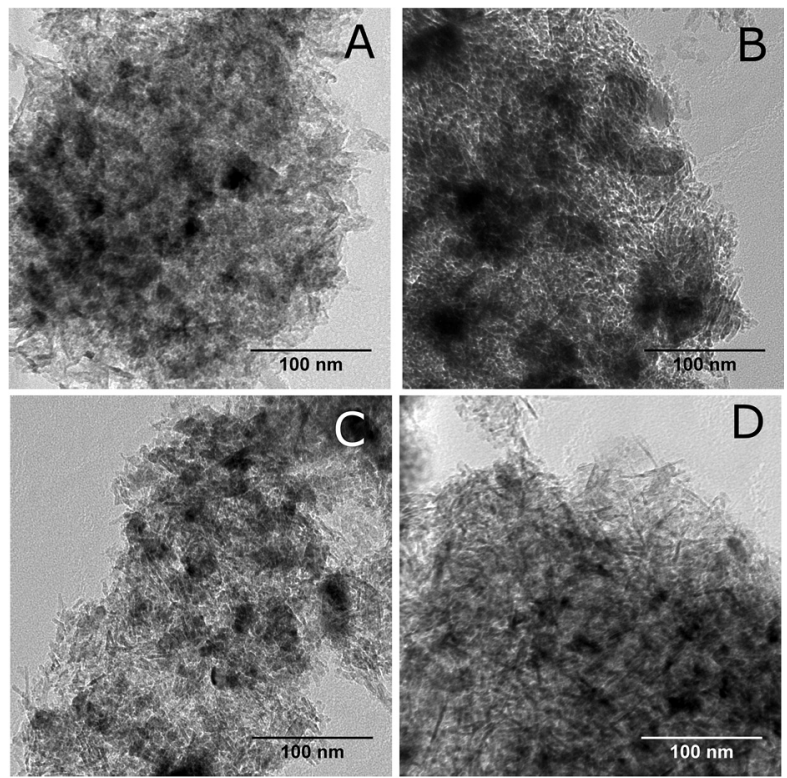

Fig. 3 TEM images of the $\mathrm{RuO}_{x} / \mathrm{Al}_{2} \mathrm{O}_{3}$ catalyst. (A) Uncalcined catalyst, (B) catalyst calcined at $350{ }^{\circ} \mathrm{C}$, (C) catalyst calcined at $350{ }^{\circ} \mathrm{C}$ and deactivated by a $\mathrm{EtNH}_{2}, \mathrm{H}_{2} \mathrm{O}$ reaction mixture in continuous flow, (D) catalyst calcined at $350{ }^{\circ} \mathrm{C}$ and deactivated by a $\mathrm{EtNH}_{2}, \mathrm{H}_{2} \mathrm{O}$ and $\mathrm{NH}_{3}$ reaction mixture in continuous flow.

containing nanoparticles, though this could not be confirmed by EDS.

Fresh and spent catalysts (obtained from activity tests under flow conditions) were imaged using TEM, as shown in Fig. 3. Darker patches shown in the images may be attributed to areas containing higher atomic weight elements, i.e. Ru-containing species. In agreement with the XRPD results, Ru containing areas appear larger in the $350{ }^{\circ} \mathrm{C}$ calcined catalyst, in comparison to the uncalcined catalyst. Both spent catalysts appear similar to each other and the fresh, uncalcined catalyst.

The BET surface area of the as synthesised $\mathrm{RuO}_{x} / \mathrm{Al}_{2} \mathrm{O}_{3}$ catalyst was $247.8 \mathrm{~m}^{2} \mathrm{~g}^{-1}$. Calcined and spent catalysts (also obtained from activity tests under flow conditions) showed slightly reduced surface areas, as would be expected following exposure to high temperatures (see Table 1).

The fresh and $350^{\circ} \mathrm{C}$ calcined catalysts were analysed using XRF. The fresh catalyst was found to contain a Ru loading of $1.33 \mathrm{wt} \%$, while the calcined catalyst contained a Ru loading of $2.06 \mathrm{wt} \%$. The lower Ru content by comparison to the $2.4 \mathrm{wt} \%$ (calculated on the basis of the presence of ruthenium
Table 1 Physical properties of fresh, calcined and spent catalysts

\begin{tabular}{lll}
\hline Catalyst & $\begin{array}{l}\text { BET surface } \\
\text { area }\left(\mathrm{m}^{2} \mathrm{~g}^{-1}\right)\end{array}$ & $\begin{array}{l}\text { Ru content }(\mathrm{wt} \%) \\
\text { determined by XRF }\end{array}$ \\
\hline $\mathrm{RuO}_{x} / \mathrm{Al}_{2} \mathrm{O}_{3}$ & 247.8 & 1.33 \\
$\mathrm{RuO}_{x} / \mathrm{Al}_{2} \mathrm{O}_{3}\left(350^{\circ} \mathrm{C}\right.$ calcined $)$ & 241.8 & 2.06 \\
$\mathrm{RuO}_{x} / \mathrm{Al}_{2} \mathrm{O}_{3}\left(350^{\circ} \mathrm{C}\right.$ calcined - & 189.6 & 1.22 \\
${\mathrm{Spent} \mathrm{in} \mathrm{EtNH}_{2} / \mathrm{H}_{2} \mathrm{O} \text { only) }}$ & \\
$\mathrm{RuO}_{x} / \mathrm{Al}_{2} \mathrm{O}_{3}\left(3500^{\circ} \mathrm{C}\right.$ calcined - & 210.0 & 1.25 \\
Spent in EtNH $\left.\mathrm{E}_{2} / \mathrm{H}_{2} \mathrm{O} / \mathrm{NH}_{3}\right)$ & & \\
\hline
\end{tabular}

in the form $\mathrm{RuO}_{2}$ ) is most likely due to hydration of the catalyst. Both catalysts contained low levels (below $0.8 \mathrm{wt} \%$ ) of $\mathrm{Na}$ and $\mathrm{Cl}$, indicating that the catalyst had been thoroughly washed during preparation. Spent catalysts that were calcined and then deactivated both with and without the presence of $\mathrm{NH}_{3}$ contained a $\mathrm{Ru}$ loading of 1.22-1.25 wt\%, indicating rehydration of the catalysts during the reaction.

The XRF and TEM results related to the fresh uncalcined, calcined and spent catalysts suggest that during the reaction the catalyst reverts to a state similar to that occurred before calcination, with a large degree of hydration and small Ru containing areas.

\section{Catalyst activity - batch reactor}

The $\mathrm{RuO}_{x} / \mathrm{Al}_{2} \mathrm{O}_{3}$ catalyst was tested for the oxidative dehydrogenation of ethylamine to acetonitrile in a similar manner to the approach used by Yamaguchi et al. for the oxidative dehydrogenation of aromatic amines. ${ }^{19}$ The initial experiments were conducted with water as the solvent and acetonitrile was produced over a range of reaction times as shown in Fig. 4, reaching $80 \%$ conversion after 18 hours at $120{ }^{\circ} \mathrm{C}$.

In the absence of ruthenium, the alumina support was found to be almost completely inactive, as shown in Table 2, supporting the proposal that the active phase of the catalyst is a ruthenium-containing species, whilst the alumina acts solely as a support material. Calcination of the catalyst at $350{ }^{\circ} \mathrm{C}$ in air prior to catalytic testing appeared to have no significant effect

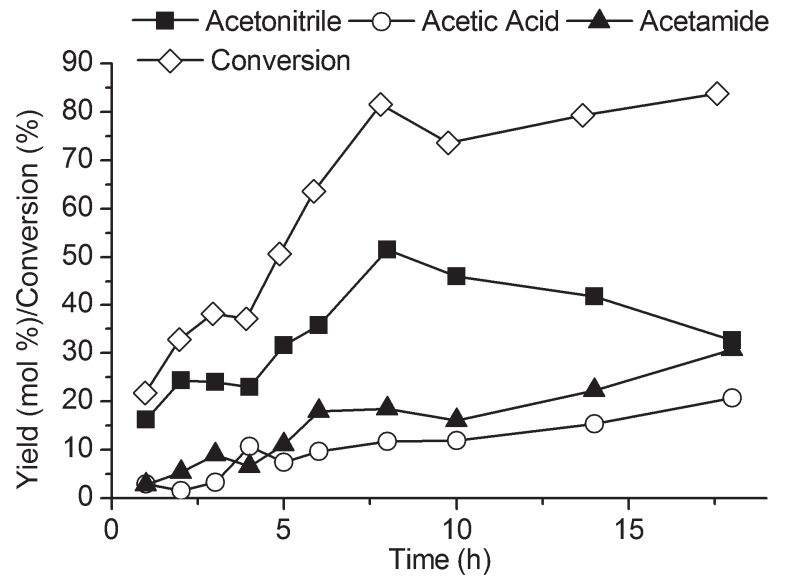

Fig. 4 The effect of reaction time on production of acetonitrile and by-products from ethylamine $(0.010 \mathrm{~mol})$ in a $\mathrm{H}_{2} \mathrm{O}$ solvent $(4 \mathrm{ml})$ with 10 bar $\mathrm{O}_{2}$, $0.425 \mathrm{~g} \mathrm{RuO}_{x} / \mathrm{Al}_{2} \mathrm{O}_{3}$ and temperature $120^{\circ} \mathrm{C}$ in the batch reactor. 
Table 2 Products of catalytic activity tests of $\mathrm{RuO}_{x} / \mathrm{Al}_{2} \mathrm{O}_{3}$ and $\mathrm{Al}_{2} \mathrm{O}_{3}$ in the batch reactor ${ }^{2}$

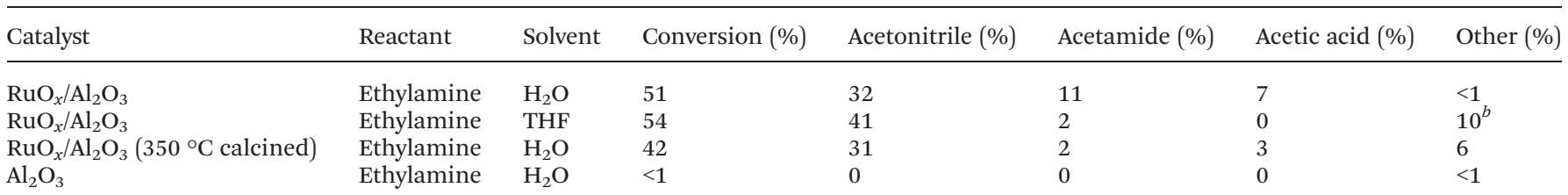

${ }^{a}$ Reaction conditions: $0.425 \mathrm{~g}$ catalyst, $0.010 \mathrm{~mol}$ reactant, 10 bar $\mathrm{O}_{2}, 120{ }^{\circ} \mathrm{C}, 5$ hours. ${ }^{b}$ Mainly $N$-ethylethanimine.

on the activity during a 5 hour reaction, also shown in Table 2 . With water as the solvent, the acetonitrile selectivity and yield was limited by production of acetamide and acetic acid by-products, suspected to be formed by hydration of the acetonitrile product followed by hydrolysis, as shown in Scheme 2. The conversion of ethylamine to acetonitrile and acetamide agrees with the findings of Yamaguchi $e t$ al., who observed the synthesis of aromatic nitriles and amides using a similar supported ruthenium catalyst in an aqueous environment. ${ }^{13,19}$

Though ammonia may be thought to reduce the conversion to acetic acid, the presence of aqueous ammonia was found to have a detrimental effect on the catalyst activity, with significantly reduced conversion, as shown in Fig. 5. Although good selectivities were achieved in the presence of ammonia (over $90 \%$ for all ammonia ratios), yields of acetonitrile remained low $(4-22 \%)$ due to the low conversion of ethylamine.

To prevent hydration of product acetonitrile to acetamide and acetic acid, the solvent was changed to THF and acetonitrile was again successfully produced over a range of reaction times, as shown in Fig. 6. When THF was used as the solvent there was little hydration of product acetonitrile and so selectivities in excess of $90 \%$ were achieved. In an attempt to prevent all hydration of the product acetonitrile, molecular sieves $(3 \AA)$ were added to the reaction, though their addition did not appear to yield any significant improvement in selectivity. The lack of improvement in selectivity is possibly due to the close proximity of the water by-product, the acetonitrile product and the catalyst when the conversion to acetonitrile is complete, increasing the likelihood of the subsequent reaction to form acetamide before the by-product water can be absorbed by the molecular sieves.

\section{Catalyst activity - continuous flow}

The oxidative dehydrogenation of ethylamine to acetonitrile was also successful under gas-phase, continuous flow conditions, as shown in Fig. 7. Water was used as a solvent for introducing ethylamine and, contrary to the results seen in the batch reactor, hydration of acetonitrile to acetamide and hydrolysis to acetic acid were not observed under any tested reaction conditions. However, under flow conditions the yield

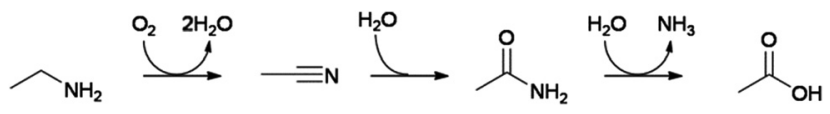

Scheme 2 Formation of acetonitrile from ethylamine, followed by hydration to acetamide and hydrolysis to acetic acid.

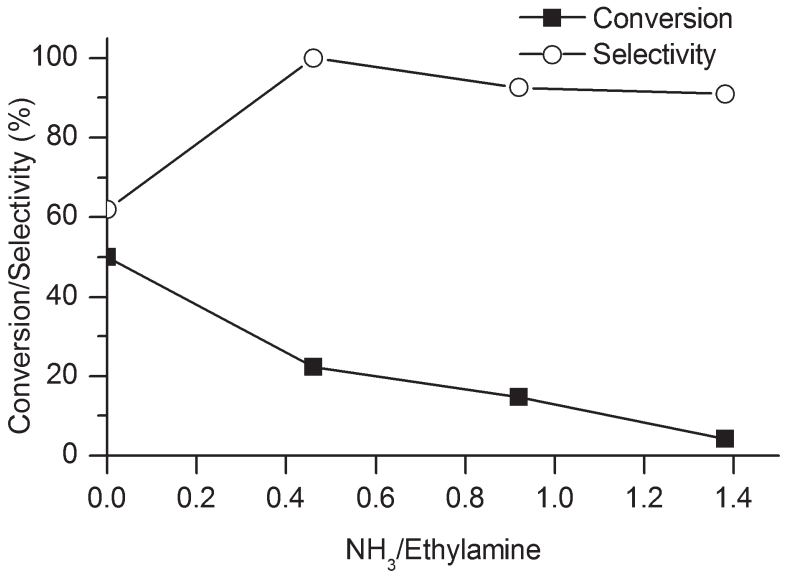

Fig. 5 Effect of increasing the $\mathrm{NH}_{3}$ : EtNH $\mathrm{H}_{2}$ molar ratio (0-1.4) on conversion of ethylamine $(0.010 \mathrm{~mol})$ and selectivity to acetonitrile in the batch reactor with a $\mathrm{H}_{2} \mathrm{O}$ solvent $(4 \mathrm{ml}), 10$ bar $\mathrm{O}_{2}$ and $0.425 \mathrm{~g} \mathrm{RuO}_{x} / \mathrm{Al}_{2} \mathrm{O}_{3}$, reaction time 5 hours, reaction temperature $120^{\circ} \mathrm{C}$.

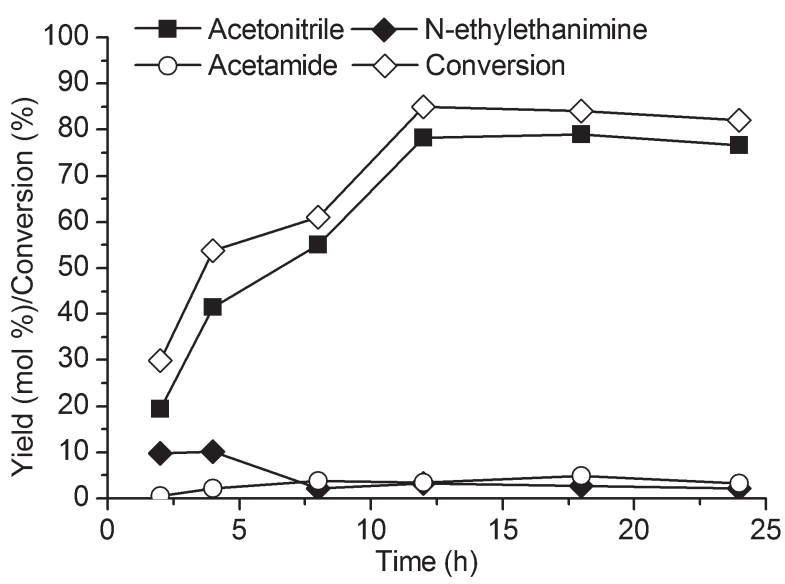

Fig. 6 The effect of reaction time on production of acetonitrile and by-products from ethylamine $(0.010 \mathrm{~mol})$ in a THF solvent $(5 \mathrm{ml})$ with 10 bar $\mathrm{O}_{2}$, $0.425 \mathrm{~g} \mathrm{RuO}_{x} / \mathrm{Al}_{2} \mathrm{O}_{3}$ and reaction temperature $120^{\circ} \mathrm{C}$.

of acetonitrile was limited by the production of acetaldehyde and $N$-ethylethanimine. Secondary imines such as $N$-ethylethanimine are well known to be formed from amines and aldehydes ${ }^{25}$ suggesting that $N$-ethylethanimine is formed by reaction of the acetaldehyde by-product with the ethylamine reactant, as shown in Scheme 3.

The selectivity to acetonitrile was slightly improved by increasing the $\mathrm{O}_{2}$ to $\mathrm{EtNH}_{2}$ molar ratio, as shown in Fig. 7. 


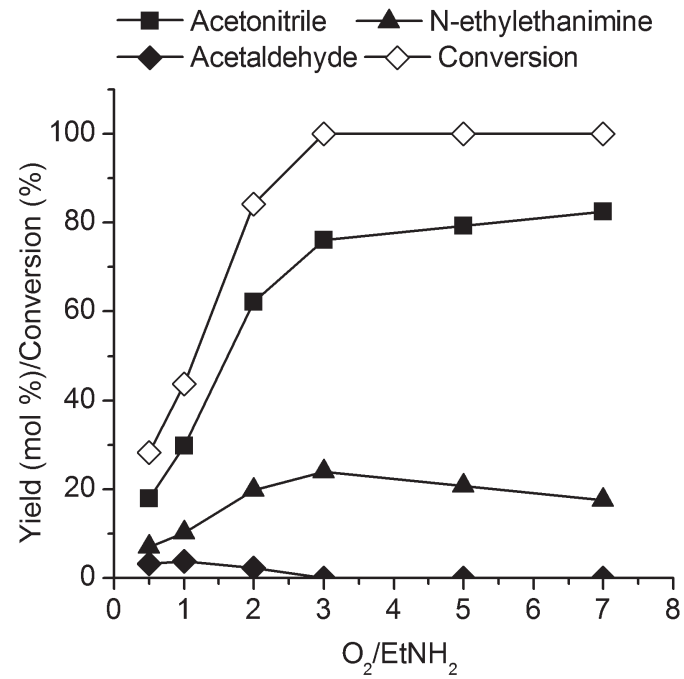

Fig. 7 Effect of the $\mathrm{O}_{2}: \mathrm{EtNH}_{2}$ molar ratio on yield of acetonitrile, acetaldehyde, $\mathrm{N}$-ethylethanimine and selectivity to acetonitrile during continuous flow reaction. Temperature $=225^{\circ} \mathrm{C}, \mathrm{WHSV}_{\text {ethylamine }}=1.0 \mathrm{~h}^{-1}$, total gas flow $=$ $150 \mathrm{~cm}^{3} \mathrm{~min}^{-1}, 0.300 \mathrm{~g} \mathrm{RuO}_{x} / \mathrm{Al}_{2} \mathrm{O}_{3}\left(350^{\circ} \mathrm{C}\right.$ calcined).

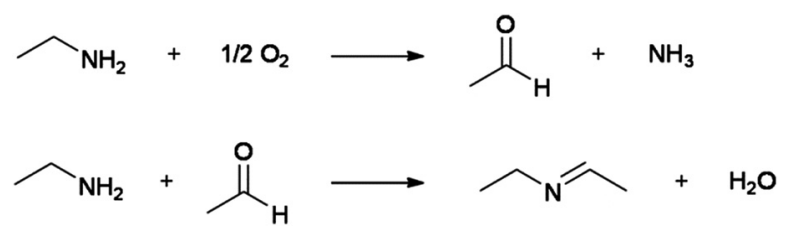

Scheme 3 Formation of acetaldehyde and $\mathrm{N}$-ethylethanimine by-products from ethylamine during continuous flow reaction.

The increased selectivity to acetonitrile with higher $\mathrm{O}_{2}$ ratios is hardly surprising when the stoichiometries of the formation of acetonitrile and acetaldehyde from ethylamine are considered, as outlined in Schemes 2 and 3.

In an attempt to decrease the synthesis rate of acetaldehyde and $\mathrm{N}$-ethylethanimine, ammonia was included in the reaction mixture in various ratios. The presence of ammonia resulted in a negligible effect on selectivity, with selectivity remaining at approximately $75 \%$ for all ammonia ratios and times on stream. However, the presence of ammonia caused the catalyst to show reduced activity (Fig. 9). When the ammonia was removed from the reactant mixture, activity increased significantly, as shown in Fig. 8. It is therefore probable that the reduction in activity caused by the presence of ammonia in the reactant mixture is due to competitive binding of ammonia to the catalyst active site, rather than degradation of the catalyst itself. Once ammonia is removed from the feedstock, it no longer blocks the catalyst active site and activity returns to a high level.

In the absence of ammonia, the catalyst proved to be surprisingly stable, with only a small decrease in conversion after 40 hours on stream. However, the catalyst was only found to have such a high stability when calcined in air, as shown in Fig. 10. Catalysts that were calcined at lower temperatures or calcined in He showed much more rapid deactivation.

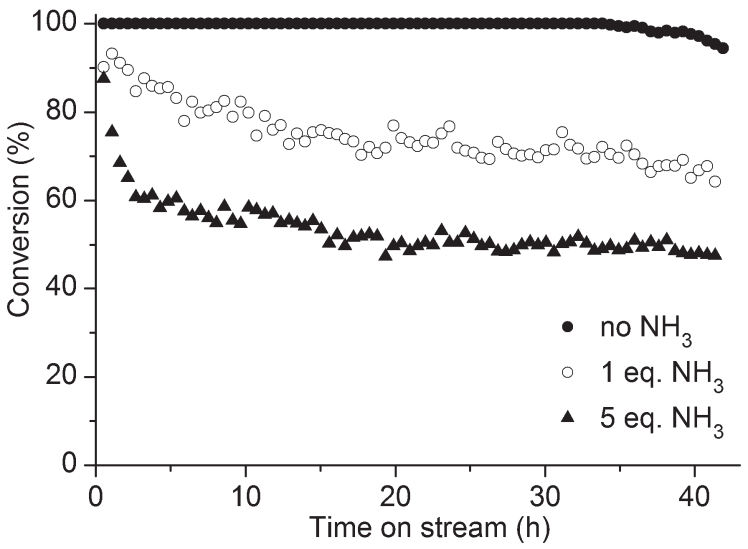

Fig. 8 Effect of time on stream on conversion of ethylamine at various $\mathrm{NH}_{3}$ : $\mathrm{EtNH}_{2}$ molar ratios $\left(0,1\right.$ and 5 eq.). Temperature $=225{ }^{\circ} \mathrm{C}, \mathrm{O}_{2}: \mathrm{EtNH}_{2}=3$, WHSV ethylamine $=1.0 \mathrm{~h}^{-1}$, total gas flow $=150 \mathrm{~cm}^{3} \mathrm{~min}^{-1}, 0.300 \mathrm{~g} \mathrm{RuO}_{x} / \mathrm{Al}_{2} \mathrm{O}_{3}$ $\left(350^{\circ} \mathrm{C}\right.$ calcined).

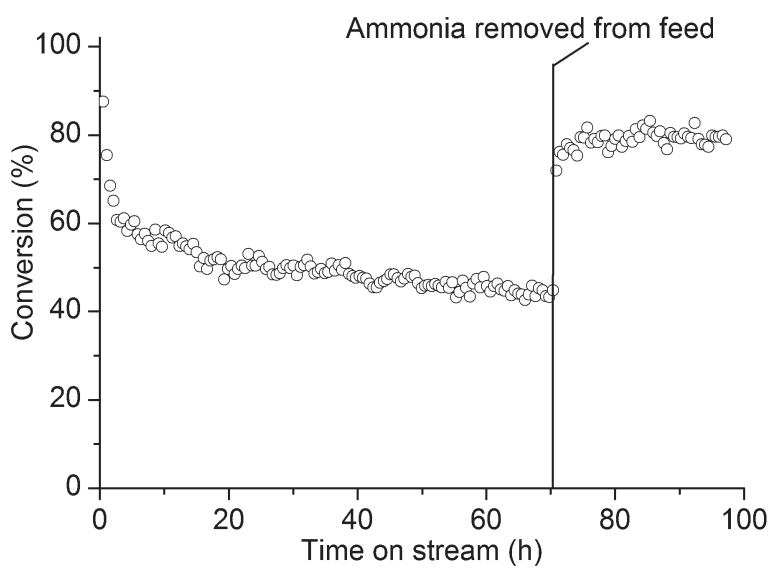

Fig. 9 Effect of removal of ammonia (5 eq.) from the feedstock on conversion of ethylamine after 70 hours on stream. Temperature $=225^{\circ} \mathrm{C}, \mathrm{O}_{2}: \mathrm{EtNH}_{2}=3$, WHSV ethylamine $=1.0 \mathrm{~h}^{-1}$, total gas flow $=150 \mathrm{~cm}^{3} \mathrm{~min}^{-1}, 0.300 \mathrm{~g} \mathrm{RuO}_{x} / \mathrm{Al}_{2} \mathrm{O}_{3}$ $\left(350^{\circ} \mathrm{C}\right.$ calcined).

- Calcined in He $(350 \mathrm{C})$ - Calcined in air $(350 \mathrm{C})$

$\nabla$ Calcined in air $(250 \mathrm{C}) \quad \Delta$ Calcined in air $(150 \mathrm{C})$

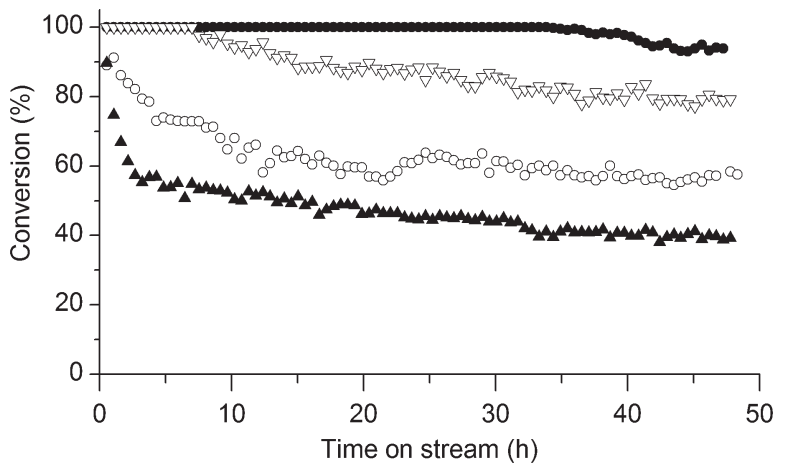

Fig. 10 Effect of time on stream on conversion of ethylamine for catalysts calcined in air or $\mathrm{He}$ at 350,250 or $150{ }^{\circ} \mathrm{C}$ for 4 hours. Temperature $=225{ }^{\circ} \mathrm{C}$, $\mathrm{O}_{2}: \mathrm{EtNH}_{2}=3, \mathrm{WHSV}_{\text {ethylamine }}=1.0 \mathrm{~h}^{-1}$, total gas flow $=150 \mathrm{~cm}^{3} \mathrm{~min}^{-1}$, $0.300 \mathrm{~g} \mathrm{RuO}_{x} / \mathrm{Al}_{2} \mathrm{O}_{3}$ 
Consideration of the catalyst activity data from both batch and continuous flow processes, as well as characterisation data, suggests that the uncalcined catalyst contains a more amorphous phase of the catalyst, whilst the calcined catalyst contains relatively large (20-25 nm) $\mathrm{RuO}_{2}$ crystallites. Both the amorphous and crystalline phases are active in both the batch and continuous flow processes, while the calcined catalyst is clearly superior in the continuous flow process, due to much higher stability under reaction conditions. The higher stability of catalysts calcined in air may be due to the presence of $\mathrm{RuO}_{2}$ nanoparticles of increased size and/or crystallinity, as observed by XRPD. The proposed high activity and stability of the $\mathrm{RuO}_{2}$ nanoparticles appear to be in disagreement with the work of Yamaguchi et al., ${ }^{17}$ who proposed a catalytic mechanism reliant on the presence of a $\mathrm{Ru}-\mathrm{OH}$ bond. However, the presence of $\mathrm{Ru}-\mathrm{OH}$ groups on the surface of $\mathrm{RuO}_{2}$ nanoparticles is highly likely, so a $\mathrm{Ru}-\mathrm{OH}$ active site is possible. Though only the $\mathrm{RuO}_{2}$ phase is visible by XRD, Oishi et al. confirmed via XPS that a similar supported ruthenium catalyst contained both $\mathrm{Ru}^{3+}$ and $\mathrm{Ru}^{4+} \cdot{ }^{18}$ The use of $\mathrm{Ru}^{3+}$ during catalyst preparation, combined with the XPS results of Oishi et al., ${ }^{18}$ suggest that the $\mathrm{RuO}_{x} / \mathrm{Al}_{2} \mathrm{O}_{3}$ catalyst reported here may also contain a mixture of ruthenium oxidation states. It is therefore possible that the catalyst reaction site includes $\mathrm{Ru}^{3+}, \mathrm{Ru}^{4+}$ or both oxidation states, which may be investigated in future via in situ XPS.

\section{Conclusions}

Alumina supported ruthenium catalysts are efficient heterogeneous catalysts for the oxidative synthesis of acetonitrile from ethylamine under both batch and continuous flow conditions. In both cases, good conversions were achieved (over $85 \%$ ) but yields were limited by the production of various by-products. Selectivities were found to be improved by optimisation of reaction conditions (80-90\%). The synthesis of acetonitrile under gas-phase, continuous flow conditions with water as the solvent is particularly noteworthy, demonstrating the possibility for a green and efficient path from bioresources such as bioethanol to acetonitrile.

\section{Acknowledgements}

The authors gratefully acknowledge funding from the European Community's Seventh Framework Programme [FP7/ 2007-2013] for SYNFLOW under grant agreement no. NMP2LA-2010-246461. We would also like to thank Katarzyna Agnieszka Janik, Lise Lotte Berring and Bodil Fliis Holten from Technical University of Denmark for support in SEM,
XRPD and BET analysis, respectively. Our thanks also go to Leon Van De Water and Dave Maclachlan from Johnson Matthey Catalysts for their help with XRF analysis.

\section{Notes and references}

1 C. Feng, Y. Zhang, Y. Zhang, Y. Wen and J. Zhao, Catal. Lett., 2011, 141, 168-177.

2 G. Centi, R. K. Grasselli and F. Trifiro, Catal. Today, 1992, 13, 661-666.

3 R. K. Grasselli, Catal. Today, 1999, 49, 141-153.

4 J. D. Idol, US Pat. 2904580, 1957.

5 E. Rojas, M. O. Guerrero-Pérez and M. A. Bañares, Catal. Commun., 2009, 10, 1555-1557.

6 Y. Li, J. Catal., 1998, 173, 511-518.

7 B. M. Reddy and B. Manohar, ChemInform, 1993, 24, 234-235.

8 S. J. Kulkarni, R. R. Rao, M. Subrahmanyam and A. V. R. Rao, J. Chem. Soc., Chem. Commun., 1994, 273-273.

9 K. S. Hayes, Appl. Catal., A, 2001, 221, 187-195.

10 M. V. George and K. S. Balachandran, Chem. Rev., 1975, 75, 491-519.

11 P. Capdevielle, A. Lavigne and M. Maumy, Synthesis, 1989, 453-454.

12 J. B. Lee, C. Parkin, M. J. Shaw, N. A. Hampson and K. I. Macdonald, Tetrahedron, 1973, 29, 751-752.

13 K. Yamaguchi and N. Mizuno, Synlett, 2010, 16, 2365-2382.

14 J. W. Kim, K. Yamaguchi and N. Mizuno, Angew. Chem., Int. Ed., 2008, 47, 9249-9251.

15 T. Oishi, K. Yamaguchi and N. Mizuno, Angew. Chem., Int. Ed., 2009, 48, 6286-6288.

16 K. Yamaguchi and N. Mizuno, Angew. Chem., Int. Ed., 2002, 41, 4538-4542.

17 K. Yamaguchi and N. Mizuno, Chem.-Eur. J., 2003, 9, 43534361.

18 T. Oishi, K. Yamaguchi and N. Mizuno, Top. Catal., 2010, 53, 479-486.

19 K. Yamaguchi and N. Mizuno, Angew. Chem., Int. Ed., 2003, 42, 1480-1483.

20 J. Wegner, S. Ceylan and A. Kirschning, Chem. Commun., 2011, 47, 4583-4592.

21 C. Wiles and P. Watts, Eur. J. Org. Chem., 2008, 1655-1671.

22 M. P. Dudukovic, F. Larachi and P. L. Mills, Chem. Eng. Sci., 1999, 54, 1975-1995.

23 R.-S. Zhou and R. L. Snyder, Acta Crystallogr., Sect. B: Struct. Sci., 1991, B47, 617-630.

24 C.-E. Boman, Acta Chem. Scand., 1970, 24, 116-122.

25 R. W. Layer, Chem. Rev., 1963, 63, 489-510. 